\title{
Alveolar soft part sarcoma: clinicopathological findings in a series of
}

\section{I cases}

\author{
Adrien Daigeler*1, Cornelius Kuhnen², Joerg Hauser ${ }^{1}$, Ole Goertz ${ }^{1}$, \\ Daniel Tilkorn ${ }^{1}$, Lars Steinstraesser ${ }^{1}$, Hans-Ulrich Steinau ${ }^{1}$ and \\ Marcus Lehnhardt ${ }^{1}$
}

\begin{abstract}
Address: ${ }^{1}$ Department of Plastic Surgery, Burn Center, Hand surgery, Sarcoma Reference Center, BG-University Hospital Bergmannsheil, Ruhr University Bochum, Buerkle-de-la-Camp-Platz 1, 44789 Bochum, Germany and 2Institute for Pathology, BG-University Hospital Bergmannsheil, Ruhr-University Bochum, Bürkle-de-la-Camp-Platz 1, 44789 Bochum, Germany

Email: Adrien Daigeler* - adrien.daigeler@rub.de; Cornelius Kuhnen - cornelius.kuhnen@rub.de; Joerg Hauser - joerg.hauser@rub.de; Ole Goertz - ole.goertz@rub.de; Daniel Tilkorn - daniel.tilkorn@web.de; Lars Steinstraesser - lars.steinstraesser@ rub.de; Hans-

Ulrich Steinau - hans-ulrich.steinau@bergmannsheil.de; Marcus Lehnhardt - marcus.lehnhardt@rub.de

* Corresponding author
\end{abstract}

Published: I July 2008

World Journal of Surgical Oncology 2008, 6:71 doi:10.1186/1477-78|9-6-71

This article is available from: http://www.wjso.com/content/6/1/7I

(c) 2008 Daigeler et al; licensee BioMed Central Ltd.

This is an Open Access article distributed under the terms of the Creative Commons Attribution License (http://creativecommons.org/licenses/by/2.0), which permits unrestricted use, distribution, and reproduction in any medium, provided the original work is properly cited.
Received: 25 March 2008

Accepted: I July 2008

\begin{abstract}
Background: Alveolar sarcoma of the soft parts (ASPS) represents a very rare entity of soft tissue sarcoma with special features such as young peak age incidence and frequent metastasis to the brain. The aim of this study was a clinicopathological analysis with special reference to treatment and outcome.
\end{abstract}

Methods: From the database of the BG-University Hospital Bergmannsheil, 1597 soft tissue sarcoma (STS) cases were reviewed and I I consecutive patients with ASPS were isolated. Data was acquired from patients' charts and contact to patients, their relatives or general practitioners, with special reference to treatment and clinical course. The average follow up time from the time of the definite operation for the primary tumor was 6.5 years. Kaplan-Meier method was used to calculate survival.

Results: Patients with localized disease who received complete resection and adjuvant radiation and who did not develop recurrence or metastatic disease within 2 years after surgery had a positive outcome. The size of the tumor, its localization, and the time of untreated growth before treatment did not influence the long-term results. All patients who developed recurrent disease also suffered from distant metastasis, reflecting the aggressive biology of the tumor. All patients with distant metastasis had the lungs and the brain affected.

Conclusion: Due to the limited number of patients with ASPS, prospective studies would have to span decades to gather a significant collective of patients; therefore, it is not possible to comment meaningfully on a possible benefit of neoadjuvant or adjuvant therapy.

We recommend wide surgical excision and, in the absence of data telling otherwise, adjuvant radiation. In cases with recurrent disease or metastasis, the prognosis is bad and further treatment will be restricted to palliation in most cases. 


\section{Background}

Alveolar soft part sarcoma (ASPS) is a very rare type soft tissue sarcoma (STS), with several unusual features, such as a very young peak age incidence and frequent metastatic spread to the brain [1]. Accounting for less than 1\% of STS, it presents at almost every part of the body with a predominance of the trunk and the proximal extremities [2-5] and usually affects patients younger than 40 years [5]. The name "alveolar" was derived from its pseudoalveolar appearance with clustered polygonal cells lacking central cohesion [4]. Recent cytogenetic studies revealed chromosome rearrangements at $\mathrm{t}(\mathrm{X} ; 17)(\mathrm{p} 11 ; \mathrm{q} 25)$ resulting in the ASPL-TFE3 fusion gene, but the origin of ASPS still remains unclear, in fact, it seems that a normal cellular counterpart for this sarcoma does not exist [6-9]. Due to its rarity, its unusual clinical course and an indolent progression of disease diagnosis and treatment has been proven to be a challenge for the pathologist and the surgeon as well. We reviewed our single center experience with ASPS over a period of 16 years with special reference to the clinical course and outcome and assessed our findings against the background of the existing literature.

\section{Methods}

From 1991 to 2007, 11 out of 1597 patients that were treated at our institution for STS were diagnosed with alveolar sarcoma of the soft parts (ASPS). Data for this case series were acquired retrospectively from the sarcoma database of BG-University Hospital Bergmannsheil. Additional information regarding the clinical course and outcome was collected from the patients' charts, and phone calls to the patients, their relatives and their general practitioners. Follow-up data were available for all patients and consisted of clinical examination, chest X-ray or computed tomography, abdominal ultrasound and CT or MRI of the tumor site and the brain in three cases. Local recurrence was defined as tumor occurrence after treatment at a site of previous operation. Metastasis was diagnosed when the tumor occurred at any other site. Summary statistics were obtained using the Kaplan-Meier method for calculating survival. Because of the low number of patients we refrained from further statistical analysis.

Four patients were female, seven were male, and the average age at time of diagnosis was 32 years (range: 19-49). The follow-up time from the time of the definite operation for the primary tumor was 78 months $/ 6.5$ years (5156 months).

\section{Histopathological examination}

In all cases the diagnosis of ASPS was confirmed by a review of the pathology slides by experienced soft tissue pathologists of our institution. In two cases (patient 5 and 9), tissue specimens were sent in for second opinion to another experienced soft tissue pathologist. In both cases, the primary diagnosis (ASPS) of our institution was confirmed.

\section{Results}

With 11 cases of alveolar sarcoma of the soft parts out of 1597 patients with soft tissue sarcoma, ASPS accounted for $0.7 \%$ of STS in our data base. Ten patients could remember the period of time the tumor was growing before definite diagnoses was made. This time ranged from one month (patient 11) to 20 years (patient 5). A correlation between the duration of untreated tumor growth and outcome could not be detected.

The site most often affected by the tumor was the thigh ( $\mathrm{n}$ $=4)$ followed by the lower leg $(n=2)$ and the thoracic wall $(n=2)$, the upper arm, the forearm, and the foot in one case each. All tumors were located intramuscular or subfascial with an average of $6.8 \mathrm{~cm}$ in largest diameter (range: $2.9-13.5 \mathrm{~cm}$ ). All patients with an unfavorable outcome had tumors below the average size (table 1 ).

At time of primary diagnosis no metastatic disease was detected in any patient. A definite tumor grading according to accepted grading classifications (Coindre classification) was not applied due to the difficulty of using grading as prognostic factor in ASPS. In one case, however, the tumor was designated a poorly differentiated variant of ASPS (patient 5).

Two patients (patient 1 and 5) had received neoadjuvant therapy (chemotherapy with etoposide, vincristine, adriamycin, ifosfamide and isolated limb perfusion with melphalan and TNF-alpha) prior to surgery because of a large tumor mass adjacent to crucial structures, leaving $70 \%$ and $30 \%$ of the tumor mass viable in the resection specimen. These two patients were alive with no evidence of disease at follow-up. Incisional biopsy was performed in six cases; fine needle biopsy in one case. Four patients were primarily resected with microscopically positive margins at other institutions and referred to BG-University Hospital Bergmannsheil for curative surgery after histological diagnosis. In all but one case (patient 8), who died of disseminated disease subsequently, free surgical margins were achieved by definite surgery.

All but three patients received adjuvant radiation therapy of the primary tumor site with a dose between 60 and $70 \mathrm{~Gy}$. One of these (patient 8) who additionally was not completely resected in the definite operation died of his disease (table 2).

Three patients (patients 2, 3, 8) developed metastases in the lung and the brain $(n=3)$, the liver $(n=2)$ and the soft tissue $(n=1)$. Two of those ( 3 and 8$)$ developed subsequent recurrent disease 29 and 11 months after surgery, 
Table I: Summarized tumor data.

\begin{tabular}{|c|c|c|c|c|c|}
\hline Patient & Localisation & Size in $\mathrm{cm}$ & TNM classification & Comments & Status \\
\hline 1 & left thigh, intramuscular & $10 \times 8 \times 4$ & ypT2 NO MO & $\begin{array}{l}\text { 70\% vital tumor in resection specimen: none } \\
\text { responder }\end{array}$ & alive, NED \\
\hline 2 & right thigh, intramuscular & $5.5 \times 4$ & PT2 NO MO & $\begin{array}{l}2 \text { tumor free lymph nodes in primary } \\
\text { specimen, lymphangiosarcomatis }\end{array}$ & DOD \\
\hline 3 & right upper arm, intramuscular & $5.6 \times 4.7 \times 3.3$ & PT2 NO MO & - & DOD \\
\hline 4 & left thigh, intramuscular & $8 \times 6,5 \times 5$ & PT2 NO MO & $\begin{array}{l}3 \text { tumor free lymph nodes in primary } \\
\text { specimen, second expert opinion by Dr. } \\
\text { Mentzel (Friedrichshafen, Germany) and } \\
\text { Prof. Fletcher (Boston, USA) }\end{array}$ & alive, NED \\
\hline 5 & right lower leg, intramuscular & $13,5 \times 9,5 \times 8,3$ & ypT2b NO MO & - & alive, NED \\
\hline 6 & right dorsum, intramuscular & $3,5 \times 2,9 \times 1.9$ & PTI NO MO & - & alive, NED \\
\hline 7 & left thigh, intramuscular & $10.5 \times 7.3 \times 5.3$ & PT2 NO MO & - & alive, NED \\
\hline 8 & left heel, subfascial & $4 \times 3 \times 2.5$ & PTI NO MO & - & DOD \\
\hline 9 & right lower leg, intramuscular & $3.5 \times 2.7 \times 1.7$ & PTI I NO MO & $\begin{array}{l}\text { Inguinal dissection because of suspicious } \\
\text { lymph nodes, ruling out lymph node } \\
\text { metastasis, second expert opinion by Prof. } \\
\text { Katenkamp, Jena (Germany) }\end{array}$ & alive, NED \\
\hline 10 & left thorax, subscapular, intramuscular & $7.8 \times 2.5 \times 1.3$ & PT2b NO MO & - & alive, NED \\
\hline 11 & right forearm, intramuscular & $2.9 \times 2.4 \times 2$ & PTIb NO MO & - & alive, NED \\
\hline
\end{tabular}

which was treated with chemotherapy (patient 3 ) in one case and lower leg amputation (patient 8) in the other case. Two patients were operated on for their metastases. One patient had the soft tissue metastases (R0) and 21 pulmonary metastases (R2) resected (patient 2); the other one (patient 3 ) was operated on for his brain metastasis (R1). All intracranial metastases were also treated with adjuvant radiation (30Gy), as well as the one soft tissue metastasis (60Gy). In addition, all patients with metastatic disease received several chemotherapeutics, but unfortunately they all died from disseminated disease after 48, 79, and 97 months. The progression free interval in these patients was 7, 9, and 12 months, respectively (table 3). All other patients were alive with no evidence of disease. The 2 year survival was calculated at $88 \%$, the 5 year survival was calculated 58\% (figure 1).

\section{Histopathology}

The firm, well vascularized tumors (figure 2) depicted a characteristic alveolar (or pseudo-alveolar) growth pattern (figure 3); the tumor cells being epitheliod and polygonal with eosinophilic cytoplasm, vesicular nuclei and prominent nucleoli. Rhomboid crystalline inclusions could be detected cytoplasmatically. A vascular invasion as a typical finding in alveolar soft part sarcoma was evident in 5 of 11 tumors (figure 4).

In general, most of the tumors showed no or only faint coagulation (tumor) necrosis. Mitotic activity was low (up to 3 mitoses in 10 high power fields), except one case (patient 7) which was characterized by 16 mitoses in 10 high power fields, including atypical ones.
Two patients (patient 1,5) had been treated systemically before tumor resection; these tumors showed regression ranging from $30-40 \%$ vital tumor tissue (patient 5: regression grade IV according to Salzer-Kuntschik) to more than $70 \%$ vital tumor (patient 1: regression grade $\mathrm{V}$ according to Salzer-Kuntschik).

Crystalline inclusions could be detected in 5 of 11 alveolar soft part sarcomas. Using immunohistochemistry, variable immunohistochemical reactions could be observed with reactivity for S-100 in 2 of 5 examined tumors, focal reactivity for desmin in 4 of 6 tumors, reactivity for actin in 1 of 7 tumors, and weak reactivity for NSE in 1 examined ASPS specimen. No reactivity could be obtained in any tumor for cytokeratins, HMB 45, myogenin, CD 31, CD 34, factor VIII, and synaptophysin.

\section{Discussion Histopathology}

The tumor harbors a specific chromosomal translocation at $\operatorname{der}(17) \mathrm{t}(\mathrm{X} ; 17)(\mathrm{p} 11 ; \mathrm{q} 25)$, often with a loss of the chromosomal region $17 \mathrm{q} 25(2,5)$. This translocation results in a fusion of TFE-3-gene (coding for a transcription factor) on chromosome Xp11 and the ASPL (RCC17)-gene of chromosome $17 \mathrm{q} 25$. The resulting ASPL-TFE3-oncoprotein causes activation of aberrant transcription [3]. A strong positive immunoreaction against TFE3 (nuclear staining) is characteristic for alveolar soft part sarcoma [1]. Other chromosomal abnormalities like trisomy 7, monosomy 8 and monosomy 18 have also been described [6].

As differential diagnosis especially, metastasis of renal cell carcinoma has to be considered: this possibility can be 
Table 2: Summarized patient's and treatment data

\begin{tabular}{|c|c|c|c|c|c|c|c|c|c|}
\hline Patient & Age/Sex & $\begin{array}{l}\text { Untreated } \\
\text { tumor } \\
\text { growth }\end{array}$ & $\begin{array}{c}\text { Initial } \\
\text { procedure }\end{array}$ & $\begin{array}{l}\text { Neodjuvant } \\
\text { treatment for } \\
\text { primary }\end{array}$ & $\begin{array}{c}\text { Definite } \\
\text { procedure }\end{array}$ & $\begin{array}{l}\text { Ajuvant } \\
\text { radiation to } \\
\text { primary }\end{array}$ & $\begin{array}{l}\text { Local and } \\
\text { recurrence } \\
\text { treatment }\end{array}$ & $\begin{array}{l}\text { Metastasis and } \\
\text { treatment }\end{array}$ & Status \\
\hline 1 & $30 / F$ & 3 months & $\begin{array}{l}\text { incisional } \\
\text { biopsy }\end{array}$ & $\begin{array}{l}\text { etoposide, } \\
\text { vincristine, } \\
\text { adriamycin, } \\
\text { ifosfamide }\end{array}$ & $\begin{array}{c}\text { R0 } \\
\text { resection }\end{array}$ & $68 \mathrm{~Gy}$ & - & - & alive, NED \\
\hline 2 & $40 / M$ & 2 years & $\begin{array}{c}\text { fine needle } \\
\text { biopsy }\end{array}$ & & $\begin{array}{c}\mathrm{RO} \\
\text { resection }\end{array}$ & $60 \mathrm{~Gy}$ & - & $\begin{array}{l}\text { right lower leg: R0 } \\
\text { resection + } \\
\text { radiation } 60 \text { Gy lung: } \\
\text { R2 resection of } 21 \\
\text { metastases brain: } \\
\text { radiation } 2 \times 30 \mathrm{~Gy}\end{array}$ & DOD \\
\hline 3 & $21 / M$ & 3 years & $\begin{array}{l}\text { incisional } \\
\text { biopsy }\end{array}$ & & $\begin{array}{c}\mathrm{RO} \\
\text { resection }\end{array}$ & $60 \mathrm{~Gy}$ & $\begin{array}{l}+/ \\
\text { adriamycin, } \\
\text { ifosfamide }\end{array}$ & $\begin{array}{l}\text { lung: adriamycin, } \\
\text { ifosfamide brain: } \\
\text { radiation } 30 \mathrm{~Gy} \\
\text { liver: - }\end{array}$ & DOD \\
\hline 4 & $26 / F$ & 70 years & $\begin{array}{l}\text { incisional } \\
\text { biopsy }\end{array}$ & & $\begin{array}{c}\mathrm{RO} \\
\text { resection }\end{array}$ & no & - & - & alive, NED \\
\hline 5 & $30 / M$ & 20 years & $\begin{array}{l}\text { incisional } \\
\text { biopsy }\end{array}$ & $\begin{array}{l}\text { ILP: Melphalan } \\
\text { + TNF-alpha }\end{array}$ & $\begin{array}{c}\mathrm{RO} \\
\text { resection }\end{array}$ & $60 \mathrm{~Gy}$ & - & - & alive, NED \\
\hline 6 & $19 / F$ & 3 years & $\begin{array}{c}\mathrm{RI} \\
\text { resection }\end{array}$ & & $\begin{array}{c}\text { R0 } \\
\text { resection }\end{array}$ & no & - & - & alive, NED \\
\hline 7 & $30 / M$ & 2 years & $\begin{array}{l}\text { incisional } \\
\text { biopsy }\end{array}$ & & $\begin{array}{c}\mathrm{RO} \\
\text { resection }\end{array}$ & $65 \mathrm{~Gy}$ & - & - & alive, NED \\
\hline 8 & $48 / M$ & $\mathrm{n} / \mathrm{a}$ & $\begin{array}{c}\mathrm{RI} \\
\text { resection }\end{array}$ & & $\begin{array}{c}\mathrm{RI} \\
\text { resection }\end{array}$ & no & $\begin{array}{l}+/ \mathrm{RO} \\
\text { resection }\end{array}$ & $\begin{array}{l}\text { lung: epirubicin, } \\
\text { ifosfamide brain: RI } \\
\text { resection liver: 5- } \\
\text { FU, cisplatin }\end{array}$ & DOD \\
\hline 9 & $24 / M$ & 6 months & $\begin{array}{c}\mathrm{RI} \\
\text { resection }\end{array}$ & & $\begin{array}{c}\mathrm{RO} \\
\text { resection }\end{array}$ & $66 \mathrm{~Gy}$ & - & no & alive, NED \\
\hline 10 & $49 / M$ & 6 months & $\begin{array}{c}\text { RI } \\
\text { resection }\end{array}$ & & $\begin{array}{c}\mathrm{RO} \\
\text { resection }\end{array}$ & $66 \mathrm{~Gy}$ & - & no & alive, NED \\
\hline 11 & $34 / \mathrm{F}$ & I month & $\begin{array}{l}\text { incisional } \\
\text { biopsy }\end{array}$ & & $\begin{array}{c}\mathrm{RO} \\
\text { resection }\end{array}$ & $70,4 \mathrm{~Gy}$ & - & no & alive, NED \\
\hline
\end{tabular}

(F: female, M: male, R0-resection: complete resection with free margins, RI-resection: resection with microscopically positive margins, R2resection: tumor masses remaining in situ, ILP: isolated limb perfusion, NED: no evidence of disease, DOD: died of disease)

excluded by history and further clinical and radiological examination, whereby metastasic renal cell carcinoma usually is positive for cytokeratin and vimentine in immunohistochemistry. Other differential diagnoses for the histopathologist include paraganglioma, adrenal cortical carcinoma, hepatocellular carcinoma, alveolar rhabdomyosarcoma, malignant melanoma and granular cell tumor. Paraganglioma may show alveolar structures as well, but, in contrast, is positive by immunohistochemistry for chromogranin and synaptophysin (neuroendo-

Table 3: Time elapsed: Time is calculated from primary diagnosis.

\begin{tabular}{|c|c|c|c|c|c|}
\hline Patient & $\begin{array}{l}\text { Time to metastasis } \\
\text { (months) }\end{array}$ & $\begin{array}{l}\text { Time to local recurrence } \\
\text { (months) }\end{array}$ & $\begin{array}{l}\text { Progression free survival } \\
\text { (months) }\end{array}$ & Follow-up (months) & Time to death (months) \\
\hline I & - & - & 156 & 156 & $\mathrm{n} / \mathrm{a}$ \\
\hline 2 & 9 & - & 9 & 48 & 48 \\
\hline 3 & 12 & 29 & 12 & 79 & 79 \\
\hline 4 & - & - & 43 & 43 & $\mathrm{n} / \mathrm{a}$ \\
\hline 5 & - & - & 99 & 99 & $\mathrm{n} / \mathrm{a}$ \\
\hline 6 & - & - & 77 & 77 & $\mathrm{n} / \mathrm{a}$ \\
\hline 7 & - & - & 125 & 125 & $\mathrm{n} / \mathrm{a}$ \\
\hline 8 & 7 & II & 7 & 97 & 97 \\
\hline 9 & - & - & 108 & 108 & $\mathrm{n} / \mathrm{a}$ \\
\hline 10 & - & - & 25 & 25 & $\mathrm{n} / \mathrm{a}$ \\
\hline 11 & - & - & 5 & 5 & $\mathrm{n} / \mathrm{a}$ \\
\hline
\end{tabular}




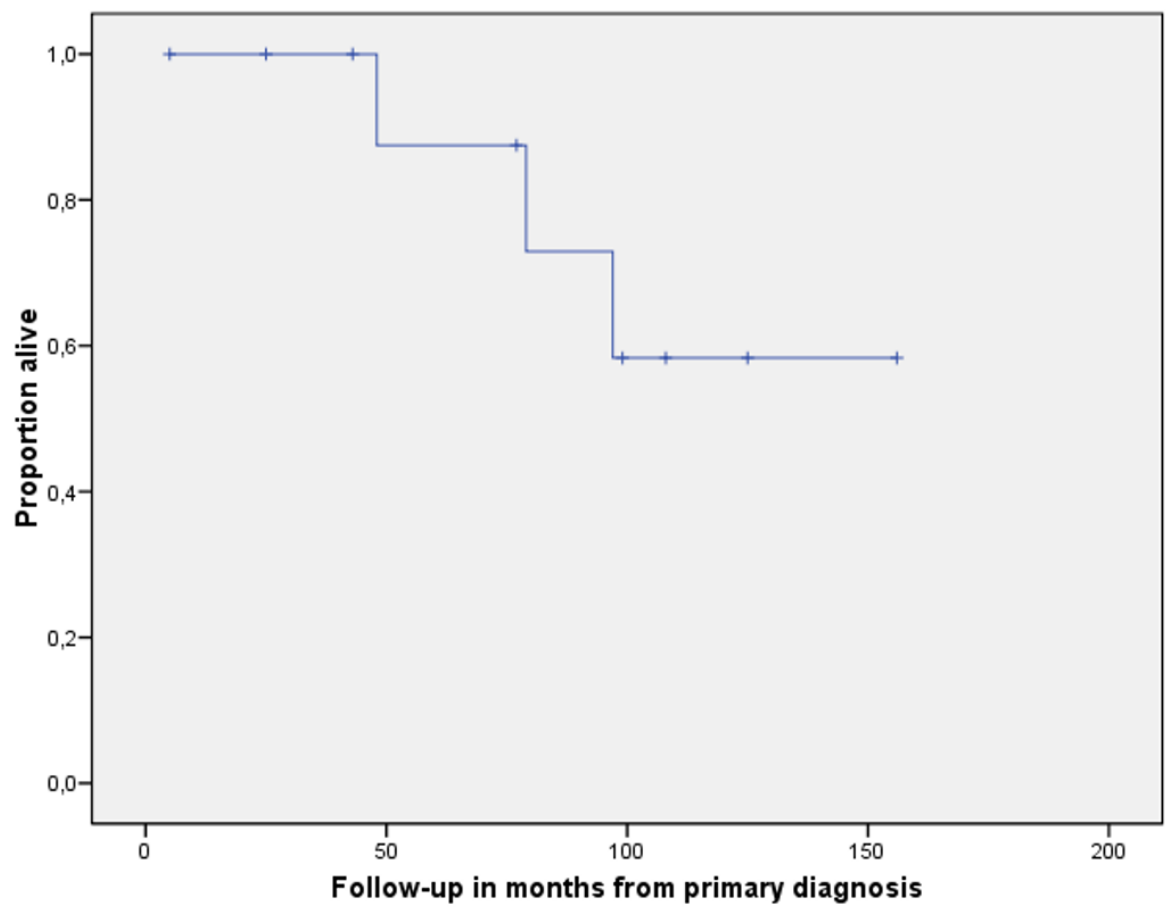

Figure I

Overall survival after primary diagnosis of ASPS. The tick marks indicate the last follow-up.

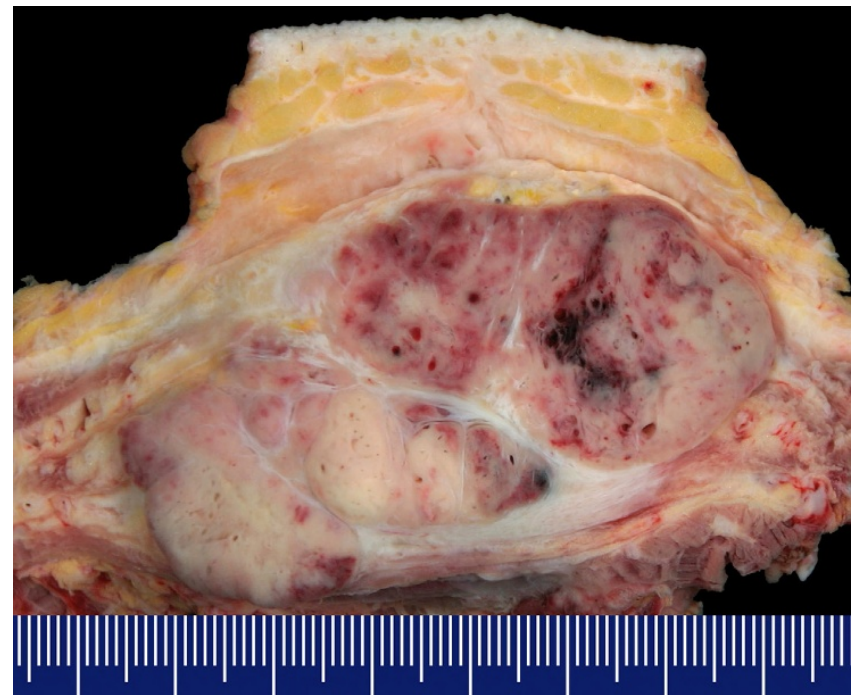

Figure 2

Macroscopic appearance of an alveolar soft part sarcoma, showing a quite solid tumor mass located within the soft tissues. Necrosis is not a striking macroscopic appearance of this sarcoma.

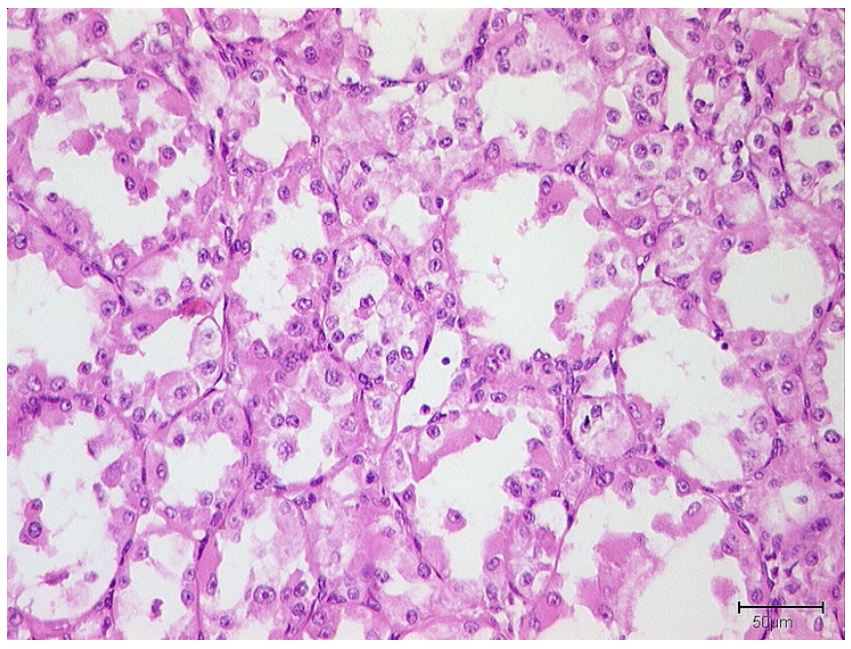

Figure 3

Histologic appearance of an alveolar soft part sarcoma: tumor growth characterized by a central loss of cohesion in cell lobules, depicting a pseudoalveolar archictecture. Round tumor cell lobules, delineated by fibrovascular septa, containing round to polygonally shaped tumor cells with eosinophilic cytoplasm, vesicular nuclei and prominent nucleoli. 


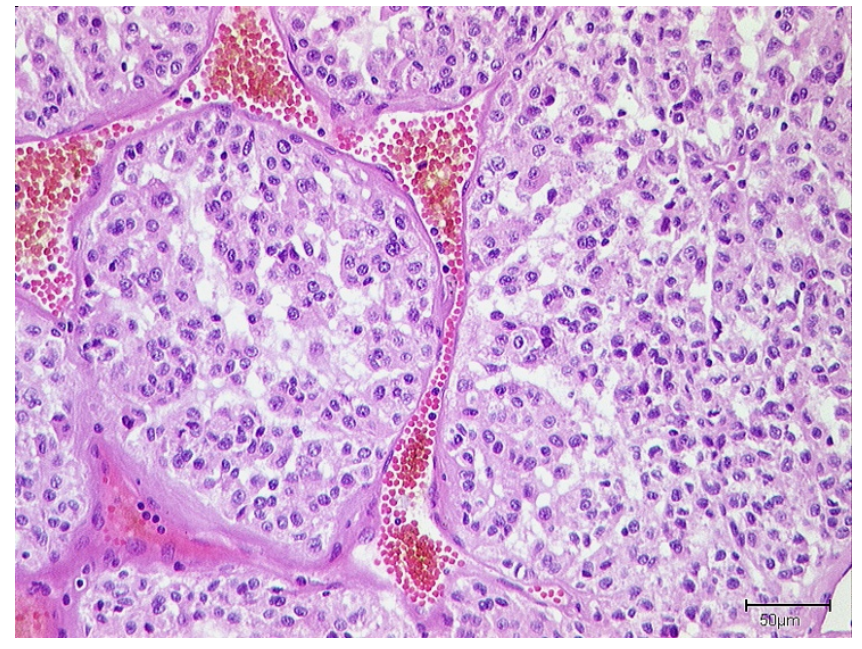

Figure 4

Poorly differentiated case of alveolar soft part sarcoma with overall lobular structure of tumor cell arrangement.

crine markers) and lacks crystalline cytoplasmatic inclusions. Metastases of adrenal cortical carcinoma and hepatocellular carcinoma may be excluded by means of immunohistochemistry (melan-A-cross reactivity in adrenal cortical carcinoma, HepPar in hepatocellular carcinoma) [1]. Alveolar rhabdomyosarcoma exhibits a skeletal muscle differentiation which can be proven by immunohistochemical stains for skeletal-muscle specific markers (myogenin, Myo D1). Malignant melanomas (especially as metastasis) have a growth pattern reminiscent of alveolar structures, but are positive for melanocytic markers like S-100 and HMB 45. A granular cell tumor does not include crystalline bundles and, in contrast to ASPS, is positive for S-100 protein.

Due to the heterogeneity of the immunohistochemical features and the small number of patients, we could not detect a true correlation of histopathological and clinical behavior in our series.

As in other studies with $0.7 \%$ of the 1597 soft tissue sarcomas, ASPS represented a very small subgroup. In contrast to previous reports $[1,4,5,10]$, all of our patients were free of lymphatic or detectable hematogenic metastasis at the time of diagnosis and were treated in curative intent. In accordance with the literature, the lesions had been growing to large tumor masses in most of our patients without causing specific symptoms for an extended time and were mostly located in the deep tissues of the thigh [3-5]. The fact that all tumors were located within or close to muscle may support the thesis that the origin of ASPS is myogenic $[11,12]$, although, due to recent genetic findings, a myogenic line of differentiation seems unlikely [7]. Interestingly and contradictory to other reports $[1,3,13]$ the size of the primary at time of diagnosis does not seem to affect the outcome because all three patients who died from their disease had primaries below the average tumor size in our series.

In this study, the age related gender ratio with a male preponderance in older patients -previously noted by Portera [5] and Ordonez [14]) - was also observed. What is more, all patients with an unfavorable outcome were male.

Complete resection of the primary, as well as the recurrent tumor manifestation, seems to be essential for local control [3-5], but cannot prevent distant metastasis in case of early spreading as seen in patient 2 and 3. Recurrent disease - that can be prevented by sufficient primary treatment in about $90 \%$ of the cases $[1,3,5]$ - itself seems to be a negative prognostic factor, probably indicating an aggressive tumor biology because all patients with recurrent disease also had distant metastases. Interestingly the metastases occurred before the local recurrence. In these cases, the preferred sequence of manifestation was lung, brain and liver. No isolated brain metastases were observed, whereas there are case reports describing those [15-17] and the large series of 102 patients by Lieberman et. al. mentioned four such cases [4]. As previously reported, lung and brain are the most common sites of metastases $[1,16,18]$ which is why X-ray or CT scans of the lung should be included in the follow-up examinations for ASPS [19]. Considering metastases to the brain almost exclusively occur synchronous or subsequent to pulmonary metastasis, the value of routine intracranial imaging is doubtful and we recommend it only in cases with neurologic symptoms. For the same reason, the same approach is recommended for abdominal MRI or CT scans for liver metastases (with the exception of ultrasound) that are performed at routine follow-ups. Due to the limited number of patients with ASPS, prospective studies would have to span decades to gather a significant collective of patients; therefore, it is not possible to comment meaningfully on a possible benefit of neoadjuvant or adjuvant therapy. In the absence of other data, however, it seems to be justified to recommend postoperative radiation to potentially increase local control rates as in other soft tissue sarcomas. The theory that radiation as single therapy is beneficial for metastatic disease of the brain must be questioned since it seems to be able to slow down growth at best, but failed to induce significant tumor shrinkage in our patients. In accordance with previous medical studies that described limited effects of radiation and chemotherapy on metastatic disease, patients who received such treatment for metastatic disease did not respond in our series[1,3-5,20]. The only patient who received neoadjuvant chemotherapy for the primary also did not respond to it, what was documented by more than $70 \%$ of the tumor remaining viable in the 
resection specimen. Only one patient who was treated with ILP with TNF-alpha and melphalan responded to that treatment, with a necrosis of $70 \%$ of the tumor.

The long term outcome of patients with localized ASPS with a 5-year disease free survival rate of $71 \%$ [5], 67\% [21], and $60 \%[4]$, respectively, and a 5 -year actuarial survival rate of $88 \%$ [5] is considered relatively favorable. From the time of diagnosis of metastatic disease, only about $10 \%$ of the patients survive longer than 5 years $[4,5]$. The clinical courses observed on our series agree with these findings. Although the progression free interval from primary diagnosis to the development of local recurrence or metastasis in three patients was short $(7,9,12$ months), patients lived with metastatic disease but had an acceptable quality of life for a considerable time $(39,54,90$ months). This prolonged survival with metastatic disease has previously been observed by other authors as well $[4,5]$. If this long survival time is due to the multimodal therapy or in spite of it cannot be determined thus far.

\section{Conclusion}

In case of acceptable patients' condition and justifiable morbidity, our approach to recurrent disease or resectable solitary metastases continues to be surgical excision followed by radiation with the aim to improve overall quality of life. Chemotherapy is only recommended in selected cases with disseminated disease. Isolated limb perfusion may represent an additional therapeutic option in order to prepare better resection conditions and improve local control in extremity ASPS.

\section{Competing interests}

The authors declare that they have no competing interests.

\section{Authors' contributions}

$\mathrm{AD}$ conceptualized the study, gathered the data and wrote the manuscript. CK performed the histopathological evaluation and interpretation of the data. JH analyzed and interpreted the data. OG acquired and weighed the data. DT drafted and revised the manuscript. LS reviewed the literature and analyzed the data. HS conceptualized and supervised the process. He gave final approval for publication. ML initiated the study and drafted the manuscript.

\section{All authors read and approved the final manuscript.}

\section{Acknowledgements}

Written informed consent was taken from all patients for publication of their case records

We thank Dr. Mentzel, Friedrichshafen (Germany), Professor Katenkamp, Jena (Germany) and Professor Fletcher, Boston (USA) for their expert second opinion and Amanda Daigeler for her formal English revision of the manuscript.

\section{References}

I. Ogose A, Morita T, Hotta T, Kobayashi H, Otsuka H, Hirata Y, Yoshida S: Brain metastases in musculoskeletal sarcomas. Jpn J Clin Oncol 1999, 29(5):245-247.

2. Lieberman PH, Foote FW Jr., Stewart FW, Berg JW: Alveolar softpart sarcoma. Jama 1966, I98(I0): I047-I05I.

3. Casanova M, Ferrari A, Bisogno G, Cecchetto G, Basso E, De Bernardi B, Indolfi P, Fossati Bellani F, Carli M: Alveolar soft part sarcoma in children and adolescents: $A$ report from the SoftTissue Sarcoma Italian Cooperative Group. Ann Oncol 2000, I I( I I): | 445- | 449.

4. Lieberman PH, Brennan MF, Kimmel M, Erlandson RA, Garin-Chesa $P$, Flehinger BY: Alveolar soft-part sarcoma. A clinico-pathologic study of half a century. Cancer 1989, 63(I): I-I3.

5. Portera CA Jr., Ho V, Patel SR, Hunt KK, Feig BW, Respondek PM, Yasko AW, Benjamin RS, Pollock RE, Pisters PW: Alveolar soft part sarcoma: clinical course and patterns of metastasis in $\mathbf{7 0}$ patients treated at a single institution. Cancer 2001, 9l(3):585-59l.

6. Joyama S, Ueda T, Shimizu K, Kudawara I, Mano M, Funai H, Takemura $\mathrm{K}$, Yoshikawa $\mathrm{H}$ : Chromosome rearrangement at I7q25 and xp I I.2 in alveolar soft-part sarcoma: $A$ case report and review of the literature. Cancer 1999, 86(7): I 246-I 250.

7. Folpe AL, Deyrup AT: Alveolar soft-part sarcoma: a review and update. J Clin Pathol 2006, 59( I I): I I 27- I I32.

8. Gomez JA, Amin MB, Ro JY, Linden MD, Lee MW, Zarbo RJ: Immunohistochemical profile of myogenin and MyoDI does not support skeletal muscle lineage in alveolar soft part sarcoma. Arch Pathol Lab Med 1999, I 23(6):503-507.

9. Ladanyi M, Lui MY, Antonescu CR, Krause-Boehm A, Meindl A, Argani P, Healey JH, Ueda T, Yoshikawa H, Meloni-Ehrig A, Sorensen $\mathrm{PH}$, Mertens F, Mandahl N, van den Berghe H, Sciot R, Cin PD, Bridge $J$ : The $\operatorname{der}(I 7) t(X ; I 7)(p I I ; q 25)$ of human alveolar soft part sarcoma fuses the TFE3 transcription factor gene to ASPL, a novel gene at I7q25. Oncogene 200I, 20(I):48-57.

10. Anderson ME, Hornicek FJ, Gebhardt MC, Raskin KA, Mankin HJ: Alveolar soft part sarcoma: a rare and enigmatic entity. Clin Orthop Relat Res 2005, 438: I44- | 48.

II. Denk H, Krepler R, Artlieb U, Gabbiani G, Rungger-Brandle E, Leoncini P, Franke WW: Proteins of intermediate filaments. An immunohistochemical and biochemical approach to the classification of soft tissue tumors. Am J Pathol 1983, I I 0(2): 193-208.

12. Mukai M, Torikata C, Iri H, Mikata A, Hanaoka H, Kato K, Kageyama $\mathrm{K}$ : Histogenesis of alveolar soft part sarcoma. An immunohistochemical and biochemical study. Am J Surg Pathol 1986, I0(3):212-218.

13. Evans HL: Alveolar soft-part sarcoma. A study of 13 typical examples and one with a histologically atypical component. Cancer 1985, 55(4):912-917.

14. Ordonez NG: Alveolar soft part sarcoma: a review and update. Adv Anat Pathol 1999, 6(3): 125-139.

15. Bindal RK, Sawaya RE, Leavens ME, Taylor SH, Guinee VF: Sarcoma metastatic to the brain: results of surgical treatment. Neurosurgery 1994, 35(2): 185-90; discussion 190-I.

16. Salvati M, Cervoni L, Caruso R, Gagliardi FM, Delfini R: Sarcoma metastatic to the brain: a series of 15 cases. Surg Neurol 1998, 49(4):44I-444.

17. Wang $\mathrm{CH}$, Lee N, Lee LS: Successful treatment for solitary brain metastasis from alveolar soft part sarcoma. J Neurooncol 1995, 25(2): 161-166.

18. Lewis AJ: Sarcoma metastatic to the brain. Cancer 1988, 6 I(3):593-60l.

19. Pollack R, Brennan M, Lawrence W Jr.: Society of Surgical Oncology practice guidelines. Soft-tissue sarcoma surgical practice guidelines. Oncology (Williston Park) 1997, I I (9): I 327-I 332.

20. Pappo AS, Parham DM, Cain A, Luo X, Bowman LC, Furman WL, Rao $B N$, Pratt $C B$ : Alveolar soft part sarcoma in children and adolescents: clinical features and outcome of II patients. Med Pediatr Oncol 1996, 26(2):81-84.

21. Auerbach HE, Brooks J]: Alveolar soft part sarcoma. A clinicopathologic and immunohistochemical study. Cancer 1987, 60(I):66-73. 